\title{
ANALISIS KELAYAKAN USAHA CILET COKLAT KOTA BANDA ACEH
}

(Feasibility Analysis of Cilet Coklat in Banda Aceh City)

\author{
Abu Naldia Fadila $B^{1}$, Indra ${ }^{1}$, Rahmaddiansyah ${ }^{1^{*}}$ \\ ${ }^{1}$ Program Studi Agribisnis, Fakultas Pertanian, Universitas Syiah Kuala
}

\begin{abstract}
Abstrak - Cilet Coklat merupakan sebuah usaha yang memproduksi berbagai macam olahan coklat dan beberapa souvenir dengan produk andalannya yaitu coklat praline. Penelitian ini bertujuan untuk menganalisis tingkat kelayakan dan prospek pengembangan usaha Cilet Coklat apabila ditinjau dari aspek pasar, aspek teknis dan aspek finansial.Metode yang digunakan dalam penelitian ini adalah metode studi kasus. Metode analisismenggunakan metode deskriptif dankuantitatif. Hasil penelitian dari aspek finansial menunjukkan bahwa Cilet Coklat layak dijalankan, karena memperoleh keuntungan bersih sebesar Rp190.465.499 selama umur usaha berjalan yaitu 19 bulan, dengan rata - rata Rp10.024.500 per bulan. Nilai R/C sebesar 1,5 pada tahun pertama dan 1,7 pada tahun kedua. Payback Period 3 bulan13 hari. Analisis aspek pasar dan teknis layak untuk dijalankan.
\end{abstract}

Kata kunci: Cilet Coklat, Kelayakan, Finansial, Teknis, Pasar

\begin{abstract}
Cilet Coklat is a business that produces a wide range of processed chocolate and some souvenirs with its flagship product, namely chocolate praline. This study aims to analyze the feasibility and prospects of business development Cilet Coklat when viewed from the aspect of the market, technical and financial aspects. The method used in this research is a case study method. The method of analysis used descriptive and quantitative. The results of the study showed that the financial aspects Cilet Coklat viable, because the net profit amounted to Rp190.465.499 over the life of the business works is 19 months, with the averages Rp10.024.500 / month. R/C of 1.5 in the first year and 1.7 in the second year. Payback Period 3 months 13 days.Analysis of the technical aspects of the market and be eligible to run.
\end{abstract}

Keywords: Cilet Coklat, Fisability, Financial, Technical, Market

\section{PENDAHULUAN}

Seiring dengan perkembangan ekonomi, kebutuhan manusia akan berbagai jenis barang dan jasa semakin meningkat. Hal ini dikarenakan kebutuhan dan selera konsumen yang terus berubah, daur hidup produk yang pendek dan persaingan yang semakin meningkat sehingga banyak produsen yang bersaing dalam menciptakan produk baru untuk mengikuti selera konsumen.

Bagi para pelaku usaha, yang perlu diperhatikan ada dua hal yaitu mengenai bagaimana daya beli masyarakat di sekitar sehingga bisa memunculkan permintaan dari masyarakat dan juga bagaimana tingkat persaingan antar produsen. Apabila permintaan meningkat memungkinkan pasar menjadi potensial dan ketika kondisi permintaan menurun menyebabkan kondisi pasar berada pada posisi yang tidak menguntungkan.

Banda Aceh memiliki beberapa produsen olahan coklat, beberapa diantaranya adalah Cilet Coklat, Lala Coklat, Tia Coklat, One4Chocolate, Buketcoklat-bna dan lain - lain. Olahan coklat yang diproduksi pun bermacam-macam, antara lain : coklat praline, minuman coklat, cake, permen, buket coklat, dll. Di tengah situasi persaingan yang ketat antar produsen coklat, seorang putra Aceh bernama Supriadi memunculkan sebuah produk inovatif yang tetap berbahan dasar coklat, dengan keterampilan dan inovasi yang dimilikinya, munculah sebuah produk bernama Cilet Coklat. 
Produk Cilet Coklat merupakan sebuah inovasi yang menarik terutama bagi kalangan muda maupun orangtua. Usaha yang pertama kali didirikan di Banda Aceh pada tahun 2014 ini memproduksi berbagai macam olahan coklat dan beberapa souvenir dengan produk andalannya yaitu coklat praline. Coklat praline adalah jenis coklat yang dicetak khusus sehingga menghasilkan bentuk unik dan lucu-lucu. Praline biasanya dibuat dari cokelat jenis coumpound atau couverture untuk hasil yang lebih enak dan sehat. Di Cilet Coklat misalnya, terdapat coklat praline yang berbentuk love, persegi, bola-bola, permen, lolipop dan coklat huruf. Model yang terakhir memungkinkan pelanggan untuk memesan coklat sesuai dengan keinginannya, misalnya ucapan selamat ulang tahun atau ucapan lainnya untuk diberikan kepada orang yang tersayang.

Kondisi pasar pada Cilet Coklat saat ini tidak selalu stabil dikarenakan produk yang dijual bukanlah produk primer yang sangat dibutuhkan oleh orang banyak, namun bukan berarti kondisi pasar yang selalu sepi pengunjung, pada saat momen - momen tertentu seperti halnya momen para mahasiswa seminar, sidang, yudisium dan wisuda merupakan momen dimana Cilet Coklat berada pada kondisi pasar yang ramai pengunjung dan berpeluang mendapatkan keuntungan yang tinggi daripada hari - hari biasanya.

Permasalahan yang dialami pada Cilet Coklat adalah usaha ini merupakan usaha barun yang belum diteliti kelayakannya dari segi aspek pasar, teknis dan finansial. Perhitungan yang dilakukan hingga saat ini hanya secara sederhana seperti perhitungan hasil pendapatan yang dilakukan setiap bulan saja tanpa memperhitungkan kelayakan dari usaha yang sedang dijalankan.

Selain itu masalah yang terjadi usaha ini belum mengetahui seberapa besar tingkat persaingan dengan pesaing lain yang memiliki usaha yang sama. Penulis juga ingin melihat strategi pasar yang diterapkan pada usaha Cilet Coklat, serta meneliti apakah usaha tersebut berpeluang untuk berkembang kedepenannya atau tidak.Tujuan dari penelitianiniadalahuntuk menganalisis tingkat kelayakan dan prospek pengembangan usaha Cilet Coklat apabila ditinjau dari aspek pasar, aspek teknis dan aspek finansial.

\section{METODOLOGI PENELITIAN}

Penelitianinidilakukandi Toko Cilet Coklat yang beralamatkan di Jalan T.Iskandar Kecamatan Ulee Kareng, simpang BPKP Kota Banda Aceh.Objekpenelitianiniterbataspada usaha produk Cilet Coklat.Ruanglingkuppenelitianinimengenai analisis kelayakan usaha produk coklat di toko Cilet Coklat Kota Banda Aceh. Metode yang digunakan pada penelitian ini adalah metode studi kasus

Metode analisis dalam penelitian ini menggunakan konsep analisis kelayakan usaha atau investasi dari pendirian suatu usaha. Analisis data dilakukan secara deskriptif dan kuantitatif. Analisis secara deskriptif dilakukan untuk menganalisis keadaan Cilet Coklat dari segi aspek pasar dan aspek teknis dengan cara menjelaskan dan menggambarkan kondisi bauran pemasaran dan teknis usaha tersebut. Aspek finansial secara kuantitatif dianalisis dengan memperhitungkan arus tunai, yaitu biaya pengeluaran, penerimaan dan laba rugi.

\section{Kriteria Analisis Aspek Pasar}

Menurut Kasmir dan Jakfar (2010) aspek pasar yang perlu dianalisis adalah penentuan strategi bauran pemasaran. Bauran pemasaran yang dipilih menggunakan 7P. Penentuan 7P dipilih, jika perusahaan tidak hanya menjual produk dalam kegiatan usahanya, tetapi ketersediaan jasa seperti pelayanan, keramahan, penentuan lokasi juga berperan penting terhadap terjualnya produk. Bauran pemasaran yang dianalisis antara lain product, price, place, promotion, process, people, phisical evidence. 
Analisis segmentasi, terget, dan posisi pasar dalam analisis pasar juga perlu dilakukan. Aspek pasar ini juga membandingkan antara usaha Cilet Coklat dengan pesaingnya berdasarkan omzet dan tempat usaha.

\section{Kriteria Analisis Aspek Teknis}

Menurut Nurmalina (2010) aspek teknis dianalisis secara deskriptif dengan melihat kebutuhan bahan baku, lokasi / pasar yang dituju, ketersediaan listrik dan air, suplai tenaga kerja, transportasi yang digunakan, layout bangunan yang diterapkan dan bagaimana secara teknis proses produksi suatu produk akan dibuat, serta jenis teknologi yang dipakai dalam pembuatan suatu produk. Dalam analisis aspek teknis ini juga kita dapat mengetahui bagaimana suatu produk dihasilkan.

\section{Kriteria Analisis Finansial}

Studi kelayakan finansial yang dilakukan adalah dengan menghitung Arus tunai yaitu arus pengeluaran meliputi biaya investasi dijumlahkan dengan biaya operasional.

Secara matematis, biaya total dirumuskan sebagai berikut:

$$
\begin{aligned}
& \text { TC }=\text { FC }+ \text { VC ................. (Soekartawi, 1995). } \\
& \text { Dimana: } \\
& \text { TC }=\text { Total cost }(\text { biaya total }) \\
& \mathrm{FC}=\text { Fixed cost }(\text { biaya tetap) } \\
& \mathrm{VC}=\text { Variable cost (biaya variabel) }
\end{aligned}
$$

Perhitungan arus penerimaan dirumuskan sebagai berikut:

$\mathrm{TR}=\mathrm{P}_{\mathrm{y}}$. $\mathrm{Y}$ . (Soekartawi, 1995).

Dimana:

$\mathrm{TR}=$ Total revenue (total penerimaan)

$\mathrm{P}_{\mathrm{y}}=$ Harga

$\mathrm{Y}=$ Produksi

Selain menghitung arus tunai, juga dilakukannya perhitungan terhadap laba rugi perusahaan, dalam analisis laba rugi dapat diperhitungkan bagaimana kondisi pendapatan perusahaan tiap tahunnya, berapa untung yang didapat dan berapa rugi yang diderita. Dalam menganalisis laba rugi, diperhitungkan berapa penerimaan perusahaan dari aktivitas penjualan lalu dikurangi dengan total biaya operasional yang menambahkan penyusutan dari biaya investasi.

\section{Revenue Cost Ratio (R/C)}

Revenue Cost Ratio (R/C) merupakan perbandingan antara penerimaan dan biaya yang dikeluarkan dalam proses produksi. Soekartawi (2002) menyebutkan bahwa rasio ini dapat digunakan untuk mengukur kelayakan usaha yang dikembangkan dengan kriteria pengambilan keputusan sebagai berikut:

1. $\mathrm{R} / \mathrm{C}>1$, maka usaha tersebut dinilai menguntungkan dan layak untuk dikembangkan,

2. $\mathrm{R} / \mathrm{C}=1$, maka usaha tersebut dalam keadaan balik modal.

3. $\mathrm{R} / \mathrm{C}<1$, maka usaha tersebut dinilai tidak layak untuk diusahakan atau tidak mampu memberikan keuntungan bagi pengusahanya.

$$
\mathrm{R} / \mathrm{C} \text { ratio }=\frac{\text { Total Penerimaan }}{\text { Total Biaya }}
$$

\section{Payback Period}

Menurut Bambang Riyanto (2004) Payback period adalah periode yang diperlukan untuk dapat menutup kembali pengeluaran investasi yang menggunakan aliran cash netto/proceed. Waktu yang diperlukan agar dana yang ditanam pada suatu investasi dapat diperoleh kembali seluruhnya.

Rumus yang dapat digunakan untuk menghitung Payback Period yaitu : 


$$
\text { Payback Period }=\frac{\text { Nilai Investasi }}{\text { Proceed(Penerimaan Investasi) }}
$$

Indikator Payback Period :

a. Periode pengembalian lebih cepat dari waktu yang ditentukan = Layak

b. Periode pengembalian lebih lama atau melebihi waktu yang telah ditentukan = Tidaklayak

c. Jika usaha proyek investasi lebih dari satu, maka periode pengembalian yang diambil adalah yang lebih cepat.

\section{Aspek - Aspek Kelayakan Usaha \\ Analisis Aspek Pasar}

HASIL DAN PEMBAHASAN

Dari analisis aspek pasar Cilet Coklat sudah menetapkan strategi pemasaran dengan bauran pemasaran 7P (price, product, promotion, place, people, phisical evidence, process) dengan baik, penetapan 7P dikarenakan Cilet Coklat bukan hanya menjual produk saja tetapi juga menjual jasa dan pelayanan. Penentuan lokasi yang strategis, jasa dalam melayani pembeli sangat penting bagi usaha seperti Cilet Coklat, sehingga strategi promosi untuk menarik konsumen sangat penting untuk diperhatikan dengan memanfaatkan sosial media yang ada saat ini. Dari segi pesaing, untuk saat ini Cilet Coklat masih berada diatas para pesaingnya, hal tersebut berdasarkan omset yang didapat per bulannya dan juga perbandingan tempat lokasi usaha berjalan.

Penetapan segmentasi produk, Cilet Coklat juga sudah mengetahui dengan pasti posisi pasar yang bisa dimasuki Cilet Coklat dengan jenis produk yang dihasilkan yaitu mahasiswa dan remaja kota Banda Aceh dan sekitarnya. Cilet Coklat juga sudah dapat memutuskan target pasar potensial untuk diusahakan perusahaan dan telah menyesuaikan produknya sesuai target pasar yang dipilih. Berdasarkan permintaan dan penawaran juga sudah dapat dinyatakan layak, walaupun penjualan perbulannya fluktuatif, namun terjadi peningkatan permintaan setiap tahunnya. Hal ini dapat ditolerir karena produk Cilet Coklat bukanlah kebutuhan pokok, sehingga penjualan terbesar hanya terjadi di event tertentu saja. Berdasarkan analisis pasar tersebut usaha Cilet Coklat layak untuk dijalankan dan memiliki prospek untuk dikembangkan.

\section{Analisis Aspek Teknis}

Analisis aspek teknis dari Cilet Coklat sudah sangat baik, ketersediaan bahan baku yang mudah didapat dan belum mengalami kendala, serta pemilihan lokasi usaha yang strategis sehingga memiliki pangsa pasar yang relatif besar karena target konsumennya yaitu para mahasiswa. Pemanfaatan jasa - jasa transportasi untuk pengiriman produk baik lokal maupun nasional mempermudah fasilitas transportasi Cilet Coklat sehingga proses membeli bahan baku ataupun menjual produk menjadi lebih lancar.

Dari aspek proses produksi, kegiatan produksi Cilet coklat dengan cara membagi proses produksi berdasarkan jenis dan waktu simpan produk, sehingga kualitas produk dapat terjaga. Dari segi layout bangunan sudah tertata rapi dan diatur sedemikian rupa dengan pembagian ruangan antara ruang produksi, ruang penyimpanan barang, dan ruang tempat produk disajikan sehingga secara umum dapat memperlancar kegiatan usaha. Secara umum aspek teknis Cilet Coklat dapat dinyatakan layak dan memiliki prospek untuk dikembangkan. Namun yang perlu disayangkan adalah ukuran toko yang kecil dan tidak adanya ketersediaan air serta mesin ginset menjadi kendala tersendiri bagi usaha tersebut, sehingga dapat menjadi bahan pertimbangan bagi pemilik usaha untuk meningkatkan usahanya menjadi lebih baik. 


\section{Analisis Aspek Finansial \\ Analisis Laba Rugi}

Analisis laba rugi merupakan analisis untuk melihat bagaimana kinerja suatu usaha pada waktu tertentu, dalam analisislaba rugi dapat diperhitungkan bagaimana kondisi pendapatan usaha tersebut setiap tahunnya, berapa untung yang didapat dan berapa rugi yang diderita.

Tabel 1. Data laporan laba rugi Cilet Coklat pada tahun pertama (2015)

\begin{tabular}{|c|c|c|c|c|c|c|}
\hline $\begin{array}{c}\text { Bula } \\
n\end{array}$ & Penerimaan & $\begin{array}{c}\text { Biaya } \\
\text { Operasional }\end{array}$ & $\begin{array}{c}\text { Biaya } \\
\text { Penyusutan }\end{array}$ & $\begin{array}{c}\text { Laba Sebelum } \\
\text { Pajak }\end{array}$ & Pajak & Laba Bersih \\
\hline 1 & Rp18.400.000 & Rp14.560.830 & Rp1.218.889 & Rp2.620.281 & Rp184.000 & Rp2.436.281 \\
\hline 2 & Rp19.580.000 & Rp14.560.830 & Rp1.218.889 & Rp3.800.281 & Rp195.800 & Rp3.604.481 \\
\hline 3 & Rp15.600.000 & Rp14.560.830 & Rp1.218.889 & -Rp179.719 & Rp156.000 & -Rp335.719 \\
\hline 4 & Rp20.650.000 & Rp14.560.830 & Rp1.218.889 & Rp4.870.281 & Rp206.500 & Rp4.663.781 \\
\hline 5 & Rp27.400.000 & Rp14.560.830 & Rp1.218.889 & Rp11.620.281 & Rp274.000 & Rp11.346.281 \\
\hline 6 & Rp25.960.000 & Rp14.560.830 & Rp1.218.889 & Rp10.180.281 & Rp259.600 & Rp9.920.681 \\
\hline 7 & Rp45.740.000 & Rp14.560.830 & Rp1.218.889 & Rp29.960.281 & Rp457.400 & Rp29.502.881 \\
\hline 8 & Rp29.180.000 & Rp14.560.830 & Rp1.218.889 & Rp13.400.281 & Rp291.800 & Rp13.108.481 \\
\hline 9 & Rp24.850.000 & Rp14.560.830 & Rp1.218.889 & Rp9.070.281 & Rp248.500 & Rp8.821.781 \\
\hline 10 & Rp24.600.000 & Rp14.560.830 & Rp1.218.889 & Rp8.820.281 & Rp246.000 & Rp8.574.281 \\
\hline 11 & Rp30.480.000 & Rp14.560.830 & Rp1.218.889 & Rp14.700.281 & Rp304.800 & Rp14.395.481 \\
\hline 12 & Rp26.800.000 & Rp14.560.830 & Rp1.218.889 & Rp11.020.281 & Rp268.000 & Rp10.752.281 \\
\hline \multicolumn{6}{|c|}{ TOTAL } & Rp116.790.972 \\
\hline \multicolumn{6}{|c|}{ Rata-rata laba bersih } & Rp9.732.581 \\
\hline
\end{tabular}

Sumber : Data Primer (diolah), 2016

Tabel 2. Data laporan laba rugi Cilet Coklat pada tahun kedua (2016)

\begin{tabular}{|c|c|c|c|c|c|c|}
\hline $\begin{array}{c}\text { Bula } \\
\mathrm{n}\end{array}$ & Penerimaan & $\begin{array}{c}\text { Biaya } \\
\text { Operasional }\end{array}$ & $\begin{array}{c}\text { Biaya } \\
\text { Penyusutan }\end{array}$ & $\begin{array}{c}\text { Laba Sebelum } \\
\text { Pajak }\end{array}$ & Pajak & Laba Bersih \\
\hline 1 & Rp22.598.000 & Rp16.915.830 & Rp1.218.889 & Rp4.463.281 & Rp225.980 & Rp4.237.301 \\
\hline 2 & Rp29.302.000 & Rp16.915.830 & Rp1.218.889 & Rp11.167.281 & Rp293.020 & Rp10.874.261 \\
\hline 3 & Rp24.262.000 & Rp16.915.830 & Rp1.218.889 & Rp6.127.281 & Rp242.620 & Rp5.884.661 \\
\hline 4 & Rp25.767.000 & Rp16.915.830 & Rp1.218.889 & Rp7.632.281 & Rp257.670 & Rp7.374.611 \\
\hline 5 & Rp35.211.000 & Rp16.915.830 & Rp1.218.889 & Rp17.076.281 & Rp352.110 & Rp16.724.171 \\
\hline 6 & Rp22.392.000 & Rp16.915.830 & Rp1.218.889 & Rp4.257.281 & Rp223.920 & Rp4.033.361 \\
\hline 7 & Rp43.112.000 & Rp16.915.830 & Rp1.218.889 & Rp24.977.281 & Rp431.120 & Rp24.546.161 \\
\hline \multicolumn{6}{|c|}{ Total } & Rp73.674.527 \\
\hline \multicolumn{6}{|c|}{ Rata-rata laba bersih } & Rp10.524.932 \\
\hline
\end{tabular}

Sumber : Data Primer (diolah), 2016

Berdasarkan perhitungan secara finansial maupun analisis laba rugi, secara umum usaha Cilet Coklat dapat dinyatakan layak dan memiliki prospek untuk dikembangkan karena walaupun penerimaan per bulannya selalu fluktuatif, namun usaha tersebut memperoleh keuntungan bersih sebesar Rp190.465.499 selama umur usaha berjalan yaitu 19 bulan, dengan rata - rata Rp10.024.500 per bulan.

\section{Revenue Cost Ratio (R/C)}

Revenue Cost Ratio (R/C) pada usaha Cilet Coklat di Kota Banda Aceh adalah sebagai berikut :

Tabel 3. Nilai R/C ratio pada usaha cilet coklat di Kota Banda Aceh

\begin{tabular}{|c|l|c|c|}
\hline No & \multicolumn{1}{|c|}{ Uraian } & Tahun 1 & Tahun 2 \\
\hline 1 & Total Penerimaan & Rp.309.240.000 & Rp.202.645.000 \\
\hline 2 & Total Biaya & Rp.206.120.000 & Rp.118.940.810 \\
\hline R/C Ratio & 1,5 & 1,7 \\
\hline
\end{tabular}

Sumber : Data Primer (diolah), 2016 
Tabel 3 menjelaskan bahwa R/C ratio pada usaha Cilet Coklat di Kota Banda Aceh sebesar 1,5 pada tahun pertama (selama 12 bulan) dan 1,7 pada tahun kedua (selama 7 bulan). Berdasarkan dengan kriteria pengambilan keputusan apabila $\mathrm{R} / \mathrm{C}$ ratio $>1$, maka usaha Cilet Coklat ini layak untuk diusahakan dan dikembangkan.

\section{Payback Period}

Payback Period pada usaha Cilet Coklat adalah sebagai berikut :

Tabel 4. Nilai Payback Period pada usaha Cilet Coklat

\begin{tabular}{|c|l|r|}
\hline No & \multicolumn{1}{|c|}{ Uraian } & Jumlah \\
\hline 1 & Total BiayaInvestasi & Rp.31.390.000 \\
\hline 2 & proceed & Rp.10.024.500 \\
\hline \multicolumn{2}{|r|}{ Payback Period } & 3.13 \\
\hline
\end{tabular}

Sumber : Data Primer (diolah), 2016

Tabel 4 menjelaskan bahwa Payback Period usaha Cilet Coklat selama umur usaha berjalan (19 bulan) adalah 3.13, yang berarti biaya investasi yang dikeluarkan sebesar Rp.31.390.000 dapat dikembalikan investasinya dalam waktu 3 bulan 13 hari. Periode pengembalian biaya investasi lebih cepat dari umur usaha berjalan sehingga usaha tersebut layak untuk dijalankan.

\section{KESIMPULAN DAN SARAN}

Berdasarkan hasil analisis aspek pasar dan aspek teknis menunjukkan bahwa usaha Cilet Coklat sudah layak dijalankan dan memiliki prospek untuk dikembangkan, dengan penetapan strategi bauran pemasaran yang baik, pemilihan lokasi yang strategis, serta proses produksi yang sederhana menjadikan usaha Cilet Coklat banyak diminati masyarakat khususnya remaja dan mahasiswa.

Berdasarkan hasil analisis aspek finansial usaha Cilet Coklat juga menunjukkan layak untuk dijalankan. Usaha Cilet Coklat memperoleh keuntungan bersih sebesar Rp.190.465.499selama umur usaha berjalan yaitu 19 bulan, dengan rata - rata Rp.10.024.500 per bulan. Nilai R/C ratio pada usaha Cilet Coklat sebesar 1,2 pada tahun pertama dan 1,5 pada tahun kedua sehingga berdasarkan kriteria pengambilan keputusan apabila $\mathrm{R} / \mathrm{C}$ ratio $>1$, maka usaha Cilet Coklat ini layak untuk diusahakan dan dikembangkan. Payback Period usaha Cilet Coklat selama umur usaha berjalan (19 bulan) yaitu 3 bulan 13 hari.

Demi kemajuan usaha Cilet Coklat ke depannya diperlukan adanya perluasan toko untuk kenyamanan konsumen sehingga tidak berdesak-desakan. Akses air dan mesin ginset juga sangat diperlukan terhadap kemajuan usaha tersebut.

Meningkatkan kreatifitas dan inovasi produk sehingga memberikan variasi baru kepada konsumen, karena kunci kesuksesan dari bisnis ini adalah bagaimana kreasi dan inovasi dalam menghasilkan produk coklat yang menarik termasuk juga rasanya yang diterima oleh masyarakat, dan kreasi tersebut bukan hanya dapat diterapkan pada produknya saja, melainkan dapat diterapkan pada tampilannya, pelayanannya, serta cara unik dalam pemasarannya.

\section{DAFTAR PUSTAKA}

Jakfar dan Kasmir. (2010).Studi Kelayakan Bisnis. Jakarta: Kencana Prenada Media Group.

Nurmalina, R. (2011). Pencegahan \& Manajemen Obesitas. Bandung :Elex Media Komputindo. 
Soekartawi.(1995). Analisis Usahatani. Jakarta: Universitas Indonesia.

Soekartawi. (2002). Prinsip Dasar Ekonomi Pertanian Teori dan Aplikasi. Jakarta: PT. RajaGrafindo.

Riyanto, B. (2004). Dasar - Dasar Pembelanjaan PerusahaanEdisi ke 4. Yogyakarta : BPFC. 